\title{
In the Iconographer's Studio. The Fashioning of New Motif Types in Pre-Iconoclastic Art
}

\begin{abstract}
What was the part played by the artists (the craftsmen/painters) in the making of new iconographical types in the Early Middle Ages? Were they given the design of what was to be illustrated all drawn up and ready from the hands of the program-makers? Or did they participate also in the work of selection from Scripture of the episodes destined to be given pictorial form? This problem is rarely reflected upon in the literature on the period, yet it calls for a clarification. A cluster of newly created or revised New Testament scenes occurs in the art of Rome shortly after the year 700 A.D., a phenomenon which opens for a study of the collaboration which took place between the artists/craftsmen and the other partakers in the process of image-creation. This is the rationale for a renewed inspection of this extraordinary series of iconographical innovations, which, as must be accentuated, were to leave their imprint on Byzantine art of the successive centuries.
\end{abstract}

Expounding on an idea of André Grabar's, in the present essay I intend to look into the creative processes by which the invention of New Testament motifs took place in Early Byzantine art. The French savant reintroduced into scholarly debate the notion of the iconographer, or motifinventor, to allow attention to be focused more closely on the specialists who were given the task of drafting the new scenes to add to the growing stock of Christian illustration, for use in manuscripts, works in metal and stone and in monumental decorations. ${ }^{1}$

One of Grabar's memorable discoveries was how "The Harrowing of Hell" scene ("The Anastasis") came about as a conflation of two single versions of the Late Roman iconography of the victorious emperor (cf. his L'empereur dans l'art chrétien, 1936/1974). According to Grabar, the creation of this scene, which sees Christ as the All-Powerful Victor, had as its prerequisite a knowledge, among those who shaped it, of Roman 'visual grammar' of the Late Empire. But to

1. In the spoken text to his Mellon Lectures in 1961, Grabar employed the term the iconographer to denote "one who creates or gives shape to (Christian) imagery". In the printed version of these lectures (Grabar 1968), this epithet has been replaced by the less suggestive "imagemaker" or simply "maker of pictures". In his scholarly works in French he nevertheless continued to use it, thus it crops up in constructs such as l'iconographe byzantin but also l'iconographe du Moyen Age, interchangeable with the expression l'imagier or even l'auteur des images; cf Grabar 1979. For his part, Grabar seems to have borrowed the expression and the concept behind it from Millet 1916, who uses it extensively. 
whom goes the honour of having extracted, from the imagery of the past, these examples of imperial art for renewed expenditure? When, in the seventh/eighth century A.D., "The Harrowing of Hell" emerged as as part of a cycle of New Testament scenes, a very long period of time had elapsed since the two scenes of the imperator triumphans had found use. By labelling the Harrowing scene a Byzantine invention, Grabar ascribed its emergence to an ambiente in which the survival of such venerable iconographical matter is probable. That is, the iconographers may have drawn their inspiration directly from monuments of Roman triumphal art still to be seen in the great Eastern capital. Textually, the story that was to be illustrated was drawn from the apocrypha, but it needed a 'skeleton' on which to be hung.

But who among these specialists possessed the erudition necessary to pick as models these ancient and symbol-laden manifestations of power? In the teams of the picture-inventors, those we subsume under the heading 'iconographers', there was obviously one group which was well versed in religious traditions and in the use of symbols, Christian or ancient. This group we may identify as the program-makers, those who formulated the ideas that were to find their artistic expression, and who took their cues from the theological authority which at the given moment determined the religious policy of the day. In close cooperation with the artists and their workshops, these experts in theology sketched out the compositions that were to compensate for the dearth of visual manifestoes occurring at intervals in ceremony and liturgy, particularly in times of dogmatic unrest and contestation.

In the case of "The Anastasis", the reasons for the peculiar reaching back into the store of ancient motifs, to create a trenchant new picture form, have been commented upon by several authors. A. Kartsonis' study from 1986 is still our best source of information concerning the factors which brought about its particular manufacture. ${ }^{2}$ Christological debates were the determining cause. In the seventh century A.D., there was, due to the tensions created by the onslaught of heretic Monotheletism, a craving for a more effective and persuasive depiction of Christ's power of winning over Death (His Human Nature waiving Death), as well as its opposite: an emblem more forceful than the existing ones to vindicate His Divine Nature.

"The Harrowing of Hell", in which He shatters the Gates of Hell, tramples on Hades and resurrects Adam and Eve and the other prisoners of the underworld, is a strikingly apt image made to serve these ends (FIG. 1). The work of cooperation that took place in the forging of this picture resulted in a design which in poignancy has few parallels in Christian iconography, to become an ever-repeated element in Byzantine art of all later periods. Those who by sifting the sources chose its content and sharpened its import, worked hand in hand with a group of artists who were capable of clothing the message in a formal language that brought to it a clarity of composition as well as an overpowering dramatic tension. The collaboration which took place here, between theologians and artists, to create a persuasive - one would be inclined to call it even visionary - imagery laden with dogma, is not (despite Grabar's effort) a theme generally explored in studies on the iconography of the epoch.

As proposed by Grabar and later upheld by Kartsonis, the first firmly dated occurrencies of

2. Kartsonis 1986. 


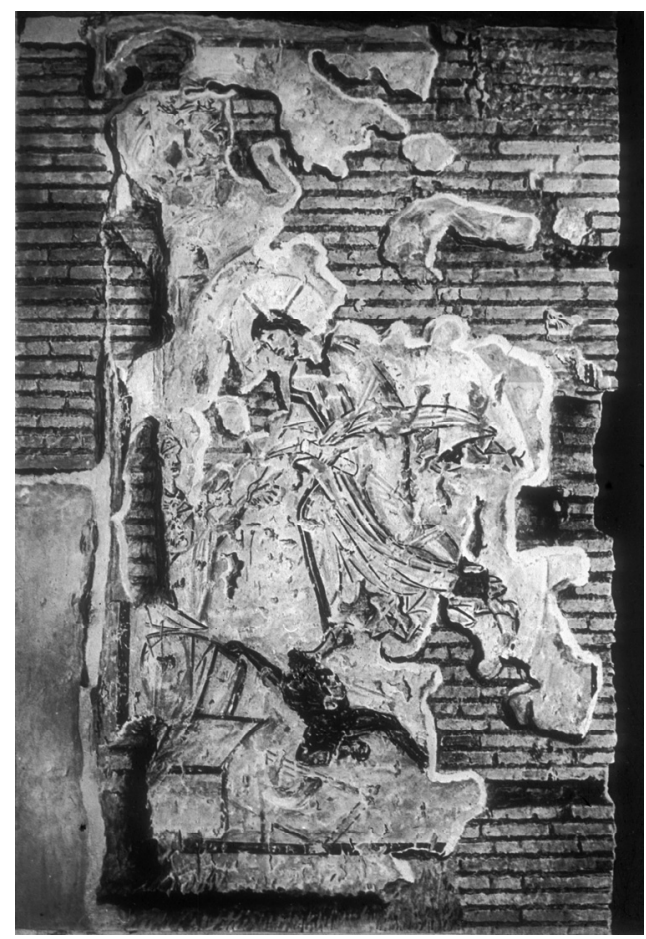

FIG. 1 - "The Harrowing of Hell" (The Anastasis), fresco. Portal towards the Palatine Ramp. S. Maria Antiqua, Rome. A.D. 705-707. After J. Wilpert, Die römischen Mosaiken und Malereien, 1917, IV.

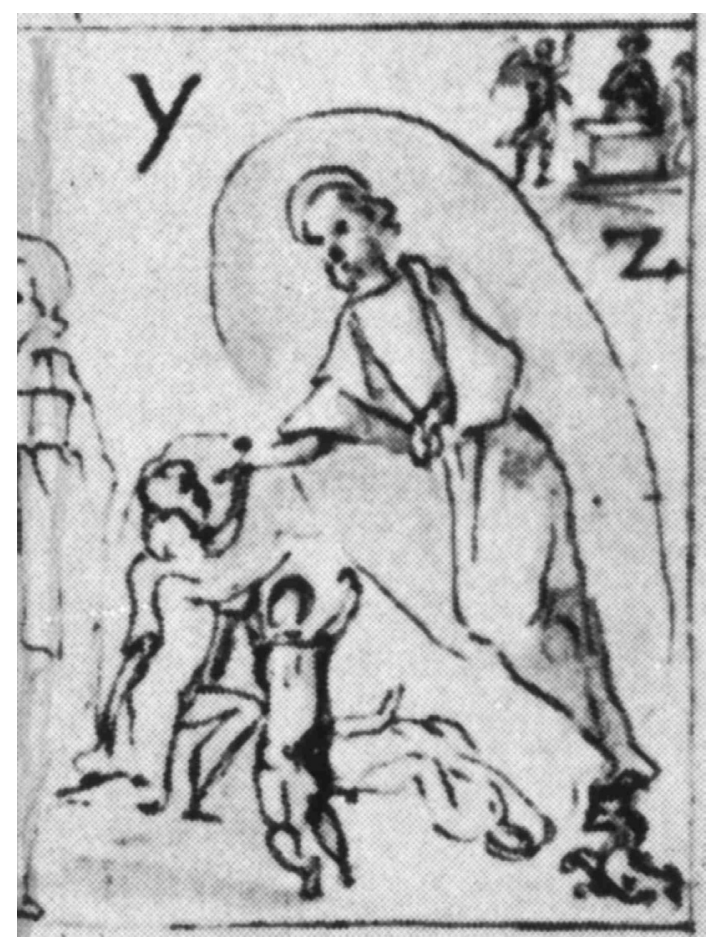

FIG. 2 - "The Harrowing of Hell" and "The Women at the Tomb", in the mosaics in the oratory of John VII (A.D. 705-707) in the Old St. Peter's. From fol. 103104 in G. Grimaldi, MS Florence, Bibl. Naz. II-III173.

"The Harrowing of Hell" are those found in the mosaics and frescoes in Rome commissioned in the early eighth century by Pope John VII (705-707 A.D.). ${ }^{3}$ One specimen of the scene is the one which was part of the cycle of stories from the Life of Christ in the mosaics made in the Old St. Peter's during the pontificate of this pope (FIG. 2); ${ }^{4}$ two more examples are seen in the frescoes

3. The scenes from John's mosaics and frescoes are discussed in Kartsonis 1986,70-81.

4. Recorded in Grimaldi's drawing (17th c.) of John VII's mosaics; see Fig. 2. The scene is described in his text to the drawing: "Resurrectio ac descensus ad limbum, pede conculcans tartara soluit à poena miseros". It was here paired with the scene of "The Women at the Grave", which from Early Christian times time had served as the emblem of the "Resurrection". This 'doubling of accent' is particular and was probably caused by unfamiliarity with the newly-coined Anastasis scene, cf. n. 10. The best and most reliable of Grimaldi's pen drawings of the Oratory mosaics is the set found in MS. Florence Bibl. Nat. II.III-173, fol. 101 (The Cycle of Sts. Peter and Paul) and fol. 103-104 (The Christ Cycle on the main wall). On the Oratory of John VII and its decoration, see Nordhagen, 1965: van Dijk, 1995; van Dijk, 1999; Ballardini, 2011. 


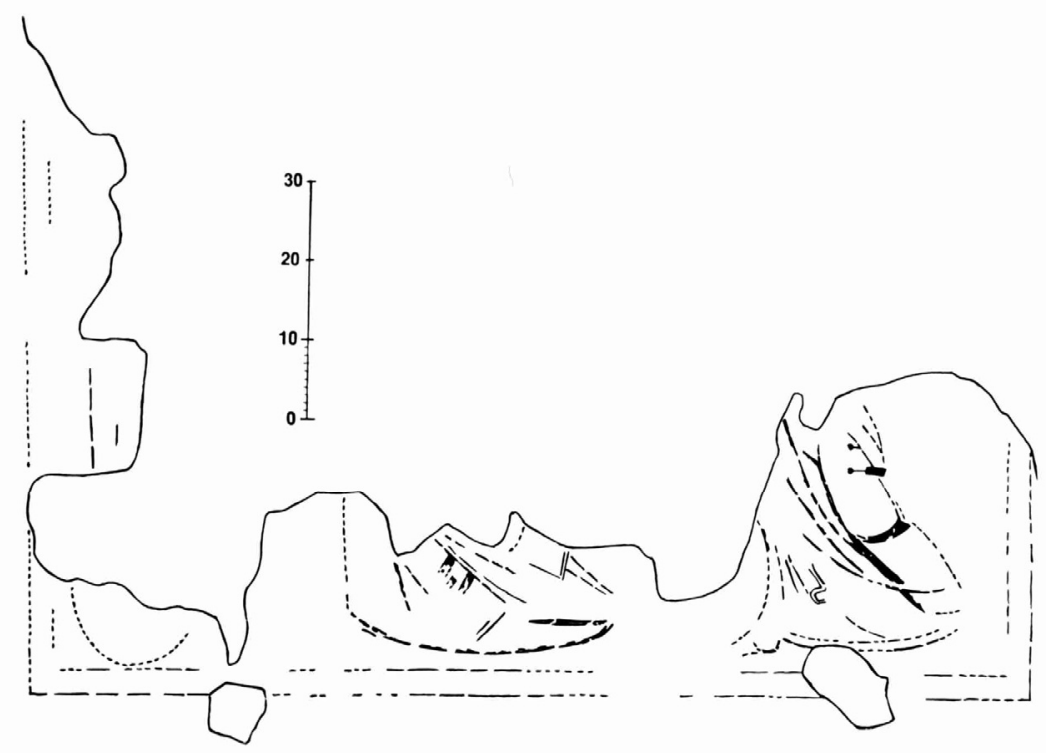

FIG. 3 - "The Apostles at The Grave", fresco. S. Maria Antiqua, Rome. A.D. 705-707. Tracing by the author.

executed under him in S. Maria Antiqua at the Forum Romanum. ${ }^{5}$ The work of composing this all-important scene probably took place in the later part of the seventh century, when the clashes between Orthodoxy and heresy reached its climax. What must be emphasized, but rarely finds mention, is that the art made under John VII is nothing less than a treasure trove of other inventions in iconography, large and small, and that many of these creations are stunning examples of the same ability for co-operation that illuminates "The Anastasis".

In the art of John VII we find four main types of iconographical creation: 1. Innovations (a main example of which is "The Anastasis"). 2. Scenes recast. 3. Addenda, i.e. new details added to older schemata. 4. Fusion, i.e. the conflation of two scenes that had formerly been separate.

To the first category belongs the scene of "The Apostles at the Grave", identified by the present author on the basis of the legible remains of it that can be perceived in the lower row of panels on the right (W) wall in the presbytery of S. Maria Antiqua. ${ }^{6}$ In it are seen two large figures, one kneeling on the ground, the other in swift walk behind him (FIG. 3). ${ }^{7}$ The scene next to it is

5. Cf. Fig. 1. For a description of the specimens of The $A n-$ astasis in S. Maria Antiqua, cf. Nordhagen, 1968 (hereafter called The Frescoes), $81 \mathrm{f}$. and 86 . The best preserved of the two, that which is depicted on the right jamb of the portal leading to the Palatine Ramp, contains in addition to the figures of Christ, Adam and Eve, and of Hades, also the tiny bust of a figure in a red chlamys, most probably one of the Old Testament Kings who people the scene in later representations of it. Also depicted in the fresco are the doors on which the Saviour tram- ples. These details were not recorded in the earliest descriptions of this image made after came to light in the excavation of the church 1900-1901.

6. The Frescoes, 31-32 and P1.XXXIII, a-b.

7. Proof that the two protagonists are apostles, is their costume: both wear whitish-green pallia and (best seen in the person on the right) light-blue tunics. This type of garment distinguishes the apostle figures in the Appearance scenes which follow on the W wall; The Frescoes, loc. cit. 
the first of four Appearance panels, the one that depicts "The Incredulity of Thomas".

Remarkable is the first emergence, in monumental art, of "The Apostles at the Grave" concomitantly with the bursting forth of "The Anastasis". Drawn from the New Testament episode of Peter and John hurrying to the Tomb, it was presumably created for the same purpose as Christ's Descent into Hell, i.e. to visualize, with a stronger accent than the Gospel scene which it was meant to replace ("The Women at the Grave", formulated in Early Christian times), the Resurrection of Christ. In this case was used the episode in the Gospel of St. John (John 20, 1-10) in which, by seeing the empty tomb, these apostles of particular status appear as witnesses to the miracle - they saw and understood (John 20, 8-9). On their authority, the Resurrection had actually taken place. This was the function of the new design. ${ }^{8}$

That "The Apostles at the Grave" never attained a position, in official iconography, comparable to that of its counterpart, "The Anastasis", is a point that should be noted. It may be surmised that in spite of its artistic élan, it did not have the impact on the viewer which had "The Anastasis": in one you had to know the Gospel story at heart to be able to identify the story and grasp its message, in the other the protagonist and his actions were easily recognized and apprehended. More important, assumedly, was the consensus among the planners of Christological cycles regarding the sublime comprehensibility of "The Anastasis" image; it illustrated, in a tight display, ideas of great complexity. Still, in "The Apostles at the Grave" the moment in the story which is illustrated is a well-chosen and charged one, and it gives an able summing up of the main elements of the episode: the Tomb with the linens strewn about inside it (deducted from later examples) and the agitated protagonists. As in "The Harrowing of Hell", the rendering of the subject is imbued with a striking energy, still palpable even with the loss of so much of the painted surface.

Despite its being eclipsed by "The Anastasis" as an emblem of the Resurrection, "The Apostles at the Grave" had a long afterlife in Byzantine art. It is among the Gospel scenes enumerated by Denys of Fourna in The Painter's Manual; its description here corresponds, in its larger lines, with what we perceive of it in S. Maria Antiqua. ${ }^{9}$ Its mention in the Manual confers upon the scene a stamp of canonicity: a new composition had been conceived which was to remain among the significant ones in post-iconoclastic art. As we shall see, yet another of the cycle stories depicted on the same wall attained a similar status. ${ }^{10}$

The scene in question is the fourth of the panels in the lower row on the $\mathrm{W}$ wall, and shows an "Appearance with The Apostles adoring Christ" ("In the Absence of Thomas"?). ${ }^{11}$ It has lost the

8. A detail of some importance is the change in the scenario which sporadically occurs with respect to this scene: while in the Gospel narrative it is "the other disciple" John - who outruns Peter and comes first to the Tomb and looks into it, their roles are reversed in some miniatures; cf. Millet 1916, Figs. 589, 598.

9. Didron 1845, 201.

10. should notice that in the series from the Life of Christ in John VII's oratory mosaics, the last scene in the cycle (after that of "The Anastasis") was not "Peter and John at the Grave", but "The Women at the Grave" according to older schemata (see Fig. 2); this feature is documented by Grimaldi's text to the drawing of the mosaics: "Quando Angelus mulieribus apparuit ad monumentum" Thus it would seem, bafflingly, that two iconographical traditions were at odds at this juncture.

11. The Frescoes, 35-38 and P1. XXXVI, a-b. 


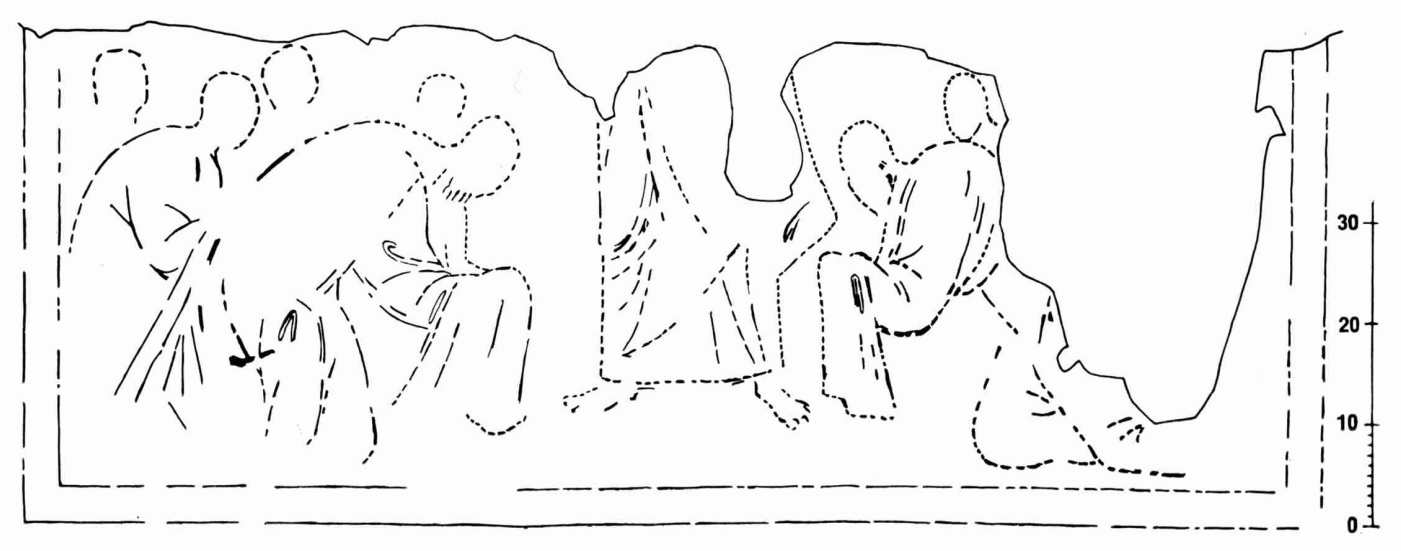

FIG. 4 - "Appearance with the Apostles adoring Christ", fresco. S. Maria Antiqua, Rome. A.D. 705-707. Tracing by the author.

upper half of the painted surface and is strongly abraded, so only the outlines and specks of colour remain of the apostles who, on their knees, deeply bowing and holding their veiled hands forward, appear left and right of a central whitish figure, Christ (FIG. 4). This is an early instance of this particular motif, the apostles in poses of intense adoration (proskynesis) flanking the Saviour. In the centuries which followed, it came to be used to illustrate several different scenes in the cycle in which an element of adoration was the theme. ${ }^{12}$

To the second of the categories enumerated above, Scenes recast, belongs "The Appearance of Christ at the Lake of Tiberias", which is the third scene in the lower register of panels on the W wall in the presbytery of S. Maria Antiqua. ${ }^{13}$ Also here, features that had been overlooked by earlier research do complete, strikingly, the picture we have of this panel. These details regard above all the two apostles we have already met as protagonists in the episode with the Apostles at the Grave, Peter and John; this prominent pair returns here as key actors in an Appearance scene which trait for trait transcribes another incident taken from the Gospel of St. John (John 21, 1-10). The text tells how Christ appears on the shore of Lake Tiberias, standing near a fire on which are laid some fishes. In the boat "the apostle whom Christ loved" - John - is the first to recognize Him; he says: "It is the Lord". Peter throws himself into the water and swims to the shore, to be the first to greet the Saviour. This is a scenario that is closely re-enacted in the panel (FIG. 5).

Part of Christ's figure, in white, is visible in the right lower corner, where a fish lies on a yellow patch of painting. Peter, marked by the titulus (p)ETRUS, is seen in a short costume ("his

12. Cf. the discussion of the scene and its parallels in The Frescoes, 36-38. Further examples are found under the 13. Ibid., 33-35 and Pl. XXXV, a-b. relevant rubrics in The Princeton Index of Christian Art. 


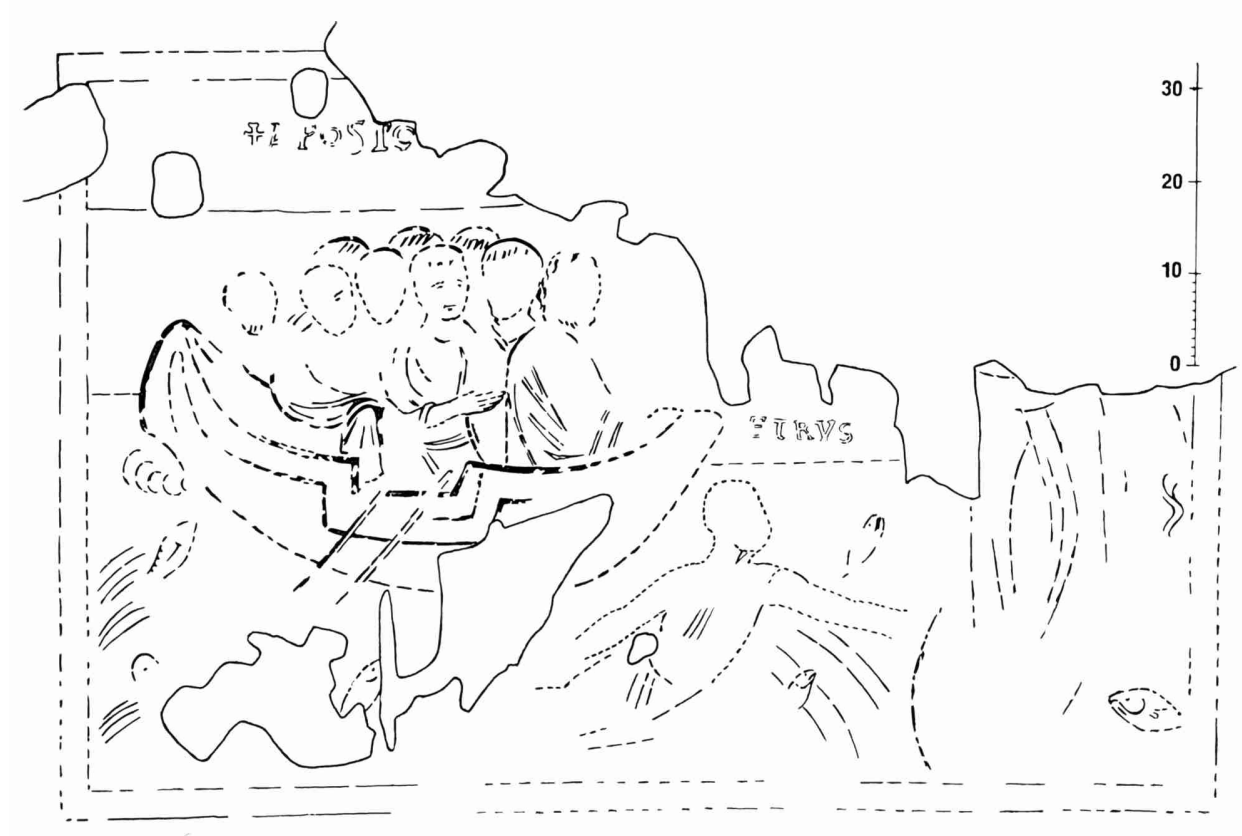

FIG. 5 - "The Appearance of Christ at the Lake Tiberias", fresco. S. Maria Antiqua, Rome. A.D. 705-707. Tracing by the author.

fisher's coat") swimming in the blue sea. In a boat on the lake are the figures of many apostles, marked APOSTO(li); among the bearded elderly men is a beardless youngish figure who holds his right hand towards Christ in a gesture of speech or exclamation; this gesture, with the thumb erect and the other fingers held tightly together, is a fixed iconographical 'sign' indicating talk. This figure must be John, who announces that he recognizes the Lord (John 21, 7). In an earlier version of the scene, in the Codex Purpureus in Munich of the sixth or seventh century A.D., none of these features appear: Christ is standing on the shore, the apostles in two boats draw nets. The reorganizing of the scene, which amounts to nothing less than a re-interpretation of it, no doubt has to do with the status of Peter and John as the all-important witnesses to both Christ's Resurrection and His Appearances. ${ }^{14}$

Again, the iconographers show an admirable discernment in their choice of the moment in the story to illustrate, and a master's eye in the carrying out of the assembling of it into a coherent, dramatic picture. The panel is meant to give 'visual proof' of the miracle of His Appearance, this is a conclusion to draw with regard to its embroidering with pregnant new details. Also this com-

14. It could be assumed that the scenes in which Peter and John are so conspicuously the protagonists, may have had their origin in homilies or pious literature in which were extolled the exploits and reactions of these two key members of Christ's circle of apostles. There being two versions of the Tomb scene, one in which John is depicted inside the tomb, the other with Peter coming first (cf. n. 8 above), makes such a second source for the scene likely. 

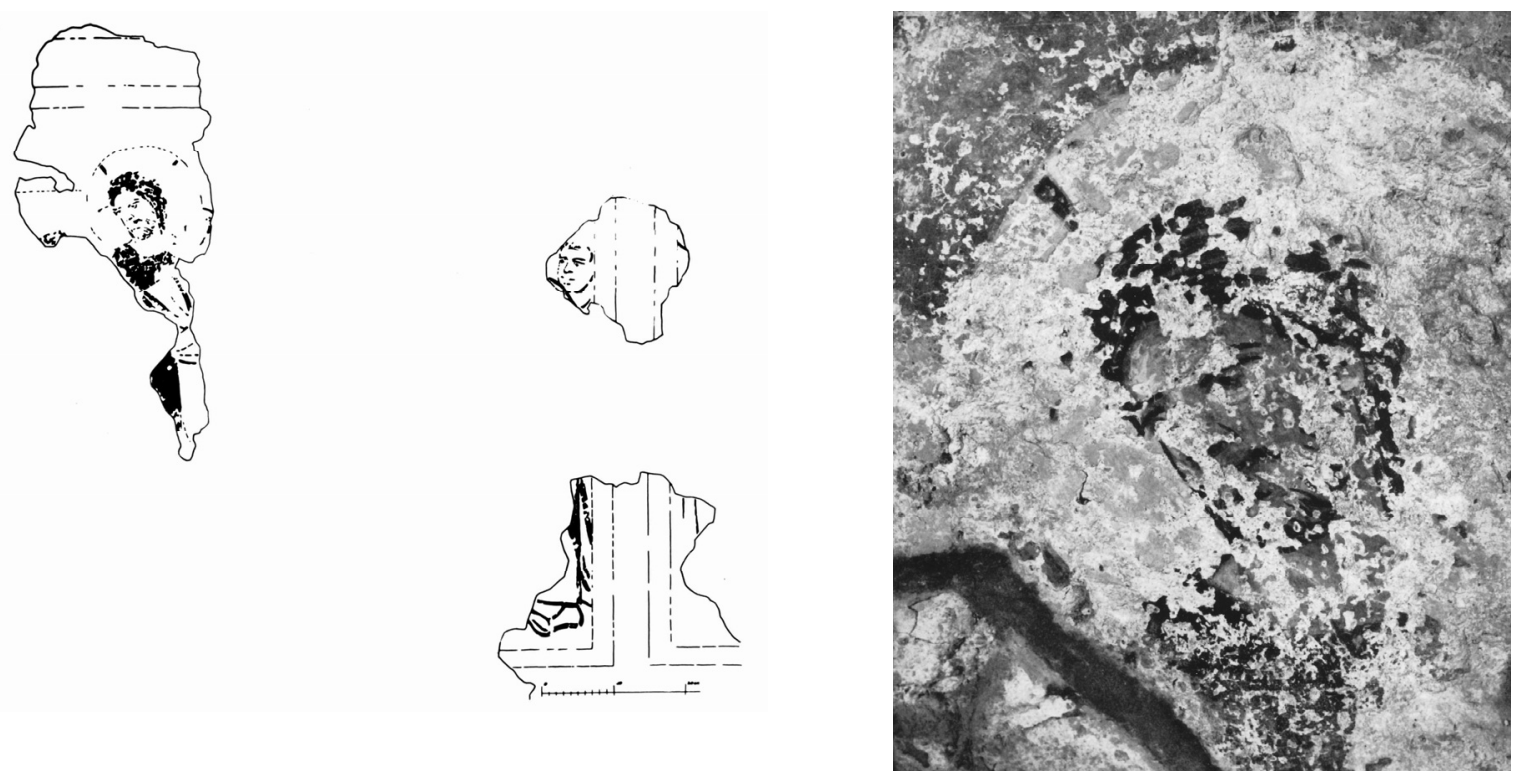

FIG. 6 - a. "The Betrayal" ("Kiss of Judas"), fresco. S. Maria Antiqua, Rome. A.D. 705-707. Tracing by the author. b. "The Betrayal", detail. Christ"s head turned sideways. Photograph by the author (The Frescoes, pl. XXV).

position is listed in the Painter's Manual, a proof of its long afterlife and of its canonicity. ${ }^{15}$ Its appearance, in the art of John VII, together with the three other 'firsts' mentioned above, is not fortuitous, but must be regarded a sign of a conscious campaign of iconographic renewal, a renewal which, presumably, unfolded in the outgoing seventh century in an influential religious and cultural centre at the shores of the Mediterranean.

An example of the third category of scenes, those which were subjected to addenda, i.e. to which were added new features to inject more meaning in their narrative, is "The Betrayal" "The Kiss of Judas"), a scene of which some fragments survive in the lowest series of panels on the left (E) wall in the presbytery in S. Maria Antiqua. ${ }^{16}$ In the centre of the scene, Christ is visible in the moment He receives the kiss, but a significant new feature is His turning away from Judas who approaches him from the right (FIG. 6 a-b). The position of His head shows that Christ glances towards the lower left part of the panel, in which the incident of Peter's cutting off the ear of Malchus must have taken place.

How the scene in its totality might have looked, is demonstrated by the representation of it in the Basilica dei SS. Martiri at Cimitile, in a fresco dated to the ninth century A.D. (FIG. 7) ${ }^{17}$ Here also, a key element of the scene is Christ's turning away from Judas and diverting His glance towards the lower left, where the episode with Peter severing Malchus' ear is depicted; important is

15. Didron 1845, 203.

16. The Frescoes 1968, 28-29 and Pls. XXIV, a-b, and $\mathrm{XXV}$. 


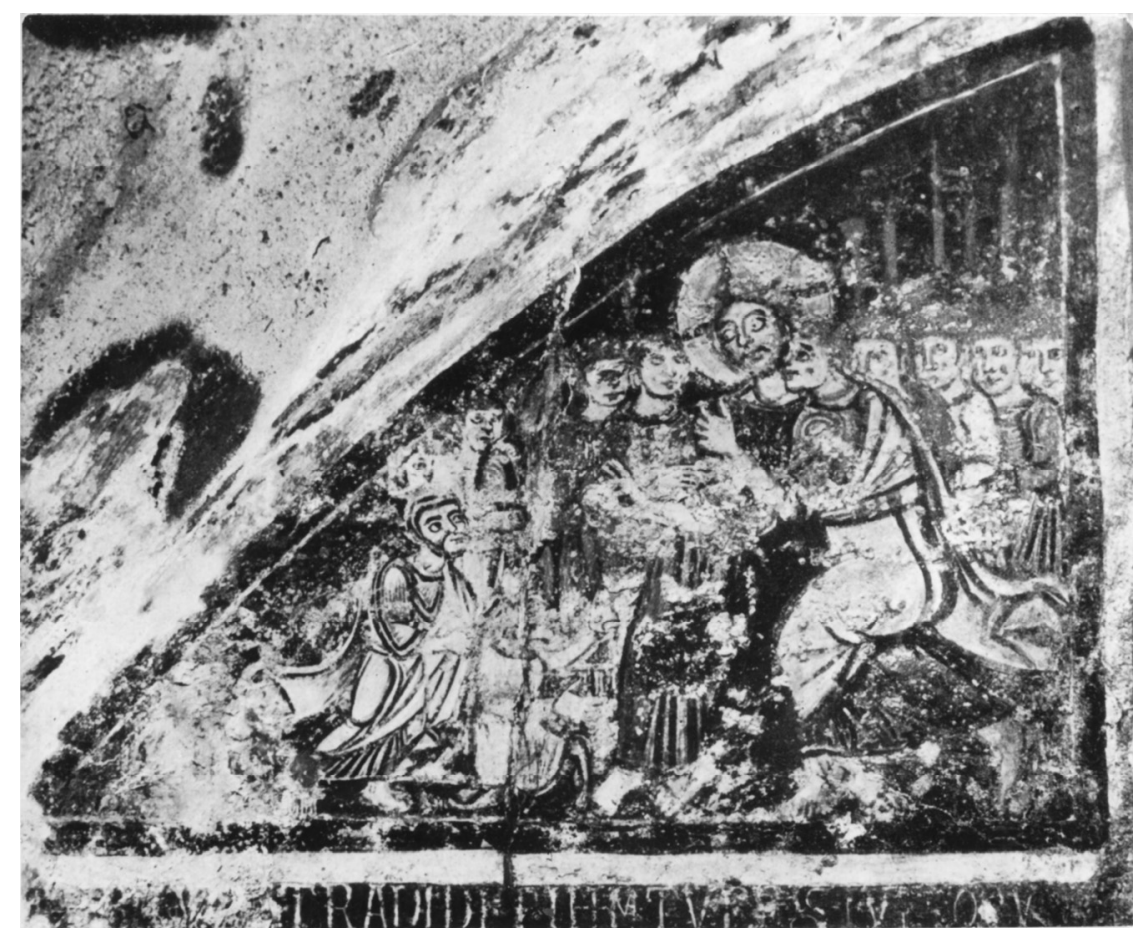

FIG. 7 - "The Betrayal", fresco. SS. Martiri, Cimitile. Ninth c. A.D. After H. Belting, Die Basilica dei SS. Martiri in Cimitile, 1962.

His blessing with His right hand outstretched towards Malchus. In an earlier version of the scene, in the mosaics in S. Apollinare Nuovo at Ravenna (sixth century), the Malchus story is suggested solely by Peter hugging the sword in its scabbard. ${ }^{18}$ By the filling in of this particular moment in the episode, "The Healing of Malchus' Ear", the last miracle performed by Jesus is underscored. With this addendum, the Betrayal scene had found its completion, in a form that became canonical and is repeated in all known later renditions of it. ${ }^{19}$

The subsequent scene on the $\mathrm{E}$ wall, in the lower series of panels, is a depiction, largely intact, of "The Carrying of the Cross", with Simon of Cyrene (SIMON CUR INEnSIS) in front, the cross on his shoulder. After him walks Christ in large strides towards the right, surrounded by Jews and soldiers (FIG. 8 a). His right arm is stretched forward, and in the hand the thumb is held stiffly upright in a gesture of speech or exclamation. ${ }^{20}$ The latter detail, the hand gesture, infuses the scene

18. Bovini 1958, Tav. XVI

19. In the Augustinus Evangel. in Cambridge (c. A.D. 600) the Malchus scene is in embryo, with Christ grasped by two men and Peter brandishing his sword; J. Thüner, 1994.
20. The Frescoes 29-30 and Pl. XXVI (panel in its totality), XXXI, b (Christ's hand). 

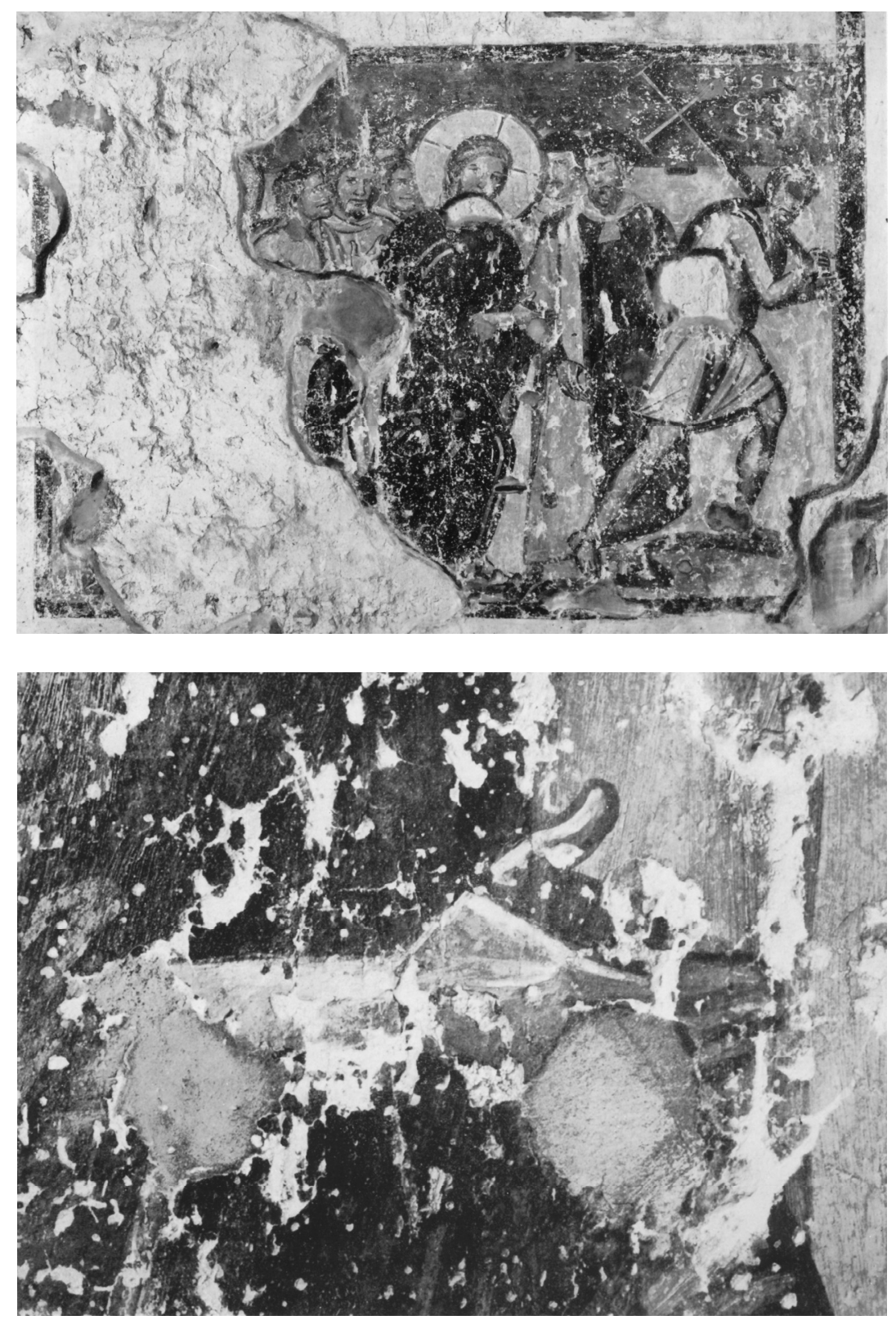

FIG. 8 - a. "The Carrying of the Cross", fresco. S. Maria Antiqua, Rome. A.D. 705-707. Gabinetto Fotografico Nazionale. b. "The Carrying of the Cross". Christ's hand. Photo by the author.

with new content (FIG. 8 b). It has to do, undoubtedly, with Christ's pronouncement, as He walked towards Golgotha, of the Doom of Mankind.

The Gospel of St. Luke, 23, 27 ff., in which the Cross-bearing is narrated, tells: “(...) And there followed him (on the road to Golgotha) a great company of people, and of women, which also bewailed and lamented him. But Jesus turning unto them said, Daughters of Jerusalem, weep 


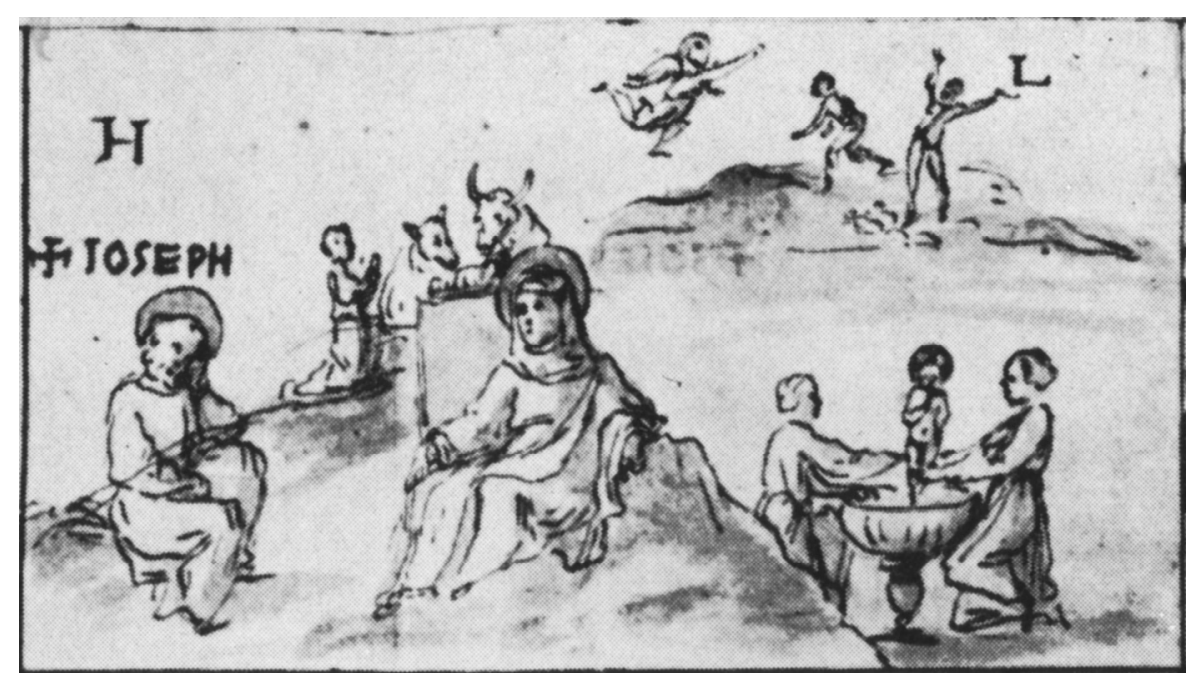

FIG. 9 - "The Nativity" with "The Annunciation to the Shepherds" incorporated. Mosaics of John VII (A.D. 705-707) in Old Peter's. From fol. 103-104 in Grimaldi, MS Florence Bibl. Naz. II-III-173.

not for me, but weep for yourselves, and for your children. For behold, the days are coming, in which they shall say, Blessed are the barren, and the wombs that never bare, and the paps which never gave suck. Then they shall begin to say to the mountains, Fall on me, and to the hills, cover us (...)". Christ's dialogue with the Women of Jerusalem on the way to Golgotha and his prophesy of the coming Doom, is an iconographical point that reappears sporadically in Golgotha scenes in Byzantine and Byzantinizing art, but not, as it appears, in the particular way it is told in the fresco in S. Maria Antiqua. ${ }^{21}$

Now to the fourth class, Fusion. An example of this category of composition was seen in the mosaics which Pope John had executed in his Oratory in Old St. Peter's, a work for which the pen drawings of Giacomo Grimaldi (17th c.) remain our best documentation (FIG. 9) ${ }^{22}$ It was an expanded version of "The Nativity", which stood among the cycle scenes on the main wall of the Oratory, positioned directly above the donor panel with the standing Maria Regina one register lower on the wall. In this compound, in which a 'normal' Nativity, with the Virgin accompanied by Joseph and surrounded by the scenes of the Child's Bath and the episode of the Midwife with the Stricken Hand, had been coupled with an "Annunciation to the Shepherds" depicted on a second plane in the background. ${ }^{23}$ This is the first documented example of the full conflation of the

21. In Millet, 1916, a chapter is devoted to Le chemin de Croix (362-375) and Les filles de Jerusalèm (376-379).

22. On the reliability of Grimaldi's drawings, cf. n. 24. The latter drawing, which contains the scene of "The Nativity", is reproduced in Nordhagen,1965, Pl. XVIII, reprinted 58-130 in idem, 1990.

23. Grimaldi describes the two episodes in the panel as follows; "Nativitas Christi, et reclinatio in Praesepe cum bove, asino ac muliere genuflexa ante Praesepe manum morbo manca habente", and "Apparitio Angeli ad pastores". On the altar-like form of the manger in which the Child rests, and the 'chalice' in which the Child's Bath takes place, both symbols of the Eucharist, cf. Ristow, 1971, 649. 
two scenes, a construct which more or less continuously was upheld in Byzantine art and by the artistic traditions branching off from it. ${ }^{24}$

To search for the exact causes of this hybridization is no easy matter. Yet, a few clues concerning its occurrence, at this particular moment in history, may be suggested. The most obvious has to do with the introduction, into the venerable image of Christ's Birth, of an Angelic apparition, in the form of the Angel who appears to the Herdsmen to impart his Message. The latter scene had remained independent prior to its blending with "The Nativity" into one image in the form we perceive in Pope John's mosaic. ${ }^{25}$ No doubt did its fusion with the Nativity scene produce an image of unprecedented persuasive power, by introducing into it the figures or 'signs' which tell of the Divine Intercession. By the union of the two scenes, visual emphasis was being placed on the Miraculous Incarnation and the Birth of the God-Man. Like in the fresco scenes studied above, the Two-Nature discussions of the late seventh century seems to have been reflected in this amalgam. However, the way by which the two scenes were linked formally gives yet another cue.

An innovative element that puts its mark on the expanded version of "The Nativity", is that present in its composition. It allowed, for the first time, what must have been a satisfying combination of two separate scenes, which, by evolving on two different planes within the panel, could be read both separately and as one story. In the similarly enlarged Nativity scene as it appears in the frescoes in S. Maria di Castelseprio in Northern Italy (eighth/ninth c.), which undoubtedly is the work of a superior artist, the trick of linking the two episodes, the Birth and the Angelic Message, is that of perspective: there is an illusion of depth by which the Angel, the upper part of whom emerges from behind the mountain on which the Virgin is reclining, is moved into the background plane (FIG. 10). ${ }^{26}$ This way of linking the two episodes is an artist's invention, brilliantly carried through. In the mosaics of John VII, it will seem that this relegation to a hind plane was performed not by this but by another device, in presenting the Angel episode in a much smaller format than that of the Birth scene unfolding in the foreground. ${ }^{27}$ In post-iconoclastic art, the Angel and the Herdsmen increased somewhat in size while the dimensions of the figures representing the Holy Family were slightly reduced. When a third element, "The Three Kings on their Way to Betlehem", was included in "The Nativity" in the 9th-10th century, and the recast

24. For the proof that Grimaldi's sketchy rendering of "The Nativity" in the pen drawings contains several correct details which were omitted in the more elaborate drawings in lead, and that, accordingly, the former bring the most trustworthy rendition of the expanded Nativity scene, see Nordhagen, 1972, 253-257, reprinted in idem, $1990,318-325$. I have not had the opportunity to consult van Dijk 1995. However, in van Dijk 1999, the author remains unaware of the methodical tool outlined in my article of 1972, by which the accuracy of pen drawings can be fully established and thereby also the authenticity of the angelic salutation which is the topic of her article, cf. her 425.

25. On a Monza ampulla (6th. c.), in an extreme conflation Shepherds and Magi flank the enthroned Virgin holding the Child; cf. Ristow, 1971, 644.
26. Bognetti, Chierici, Capitani d'Arzago, 1948, Tav. XXXVII.

27. Given the sketchiness of Grimaldi's drawing and its general simplification of the scenes in the Cycle, it cannot be excluded that the crucial trait, the Angel appearing from behind the hill, was found here too. Yet, in two somewhat later examples of the conflated scene, found in Carolingian manuscripts from Tour, The Prüm Gospels and The Sacramentary of Marmoutiers, the hill is absent; cf. M. Schapiro, 1979, 97. "The Angel behind the hill", in the form seen at Castelseprio, reappears after Iconoclasm and is repeated in many Middle-Byzantine representations of the scene; cf. Wilhelm, 1994, 97-98, 1 (Menologium of Basil II, ca. 1100); 4 (Martorana, Palermo. 12th c.). 


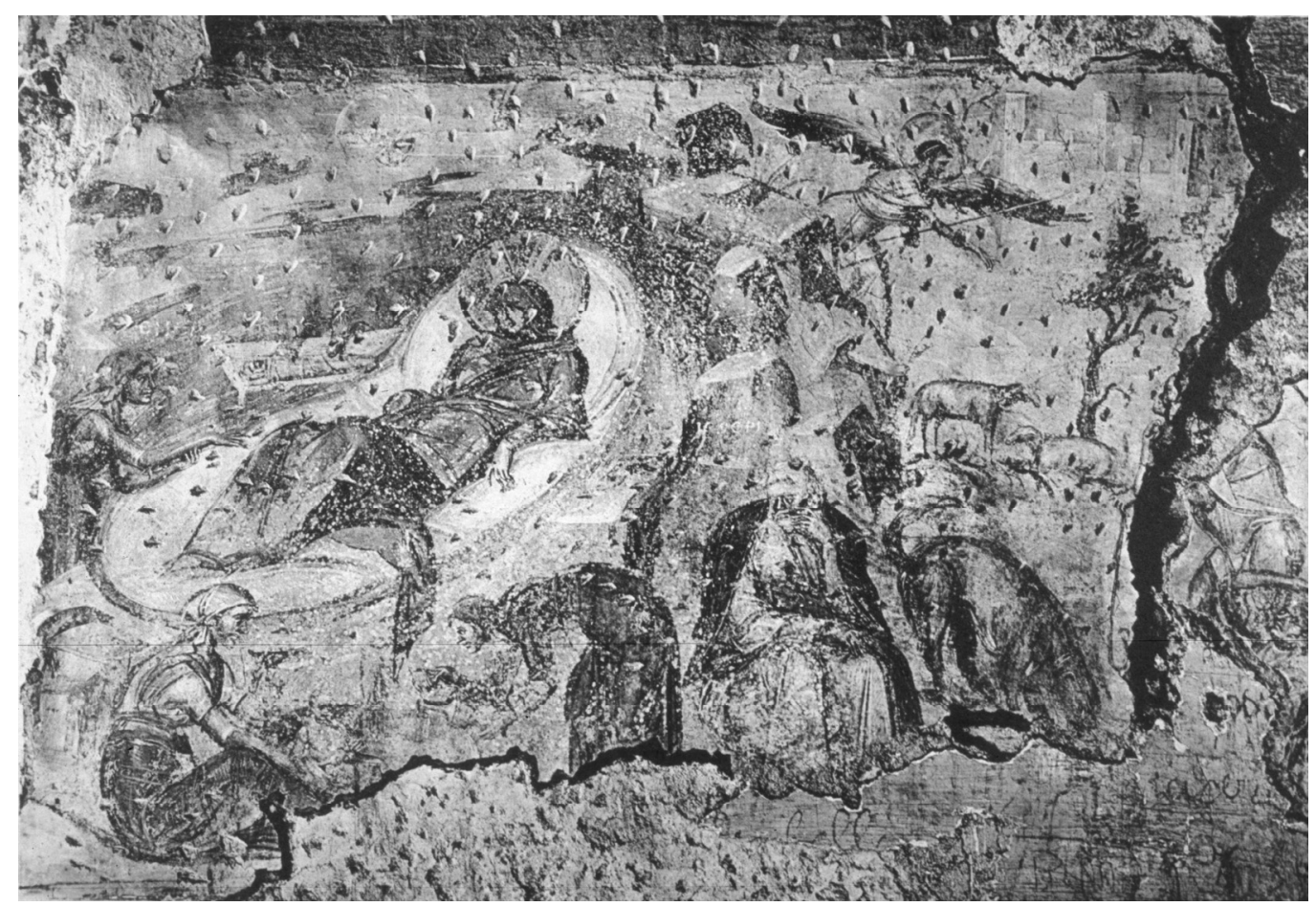

FIG. 10 - "The Nativity" with, in the foreground, The Virgin, Joseph, The Bathing of the Child and the Midwife with the Stricken Hand before the Crib; in the background, "The Annunciation to the Shepherds". Castelseprio, fresco. Eighth/ninth c. A.D. From K. Weitzmann, The Fresco Cycle of S. Maria di Castelseprio, Princeton 1952.

scene became even more crowded, a further diminution took place in the figures of the added episodes, Mary and Joseph, especially the former, retaining a stature somewhat larger than the other figures which now peopled the scene.

The examples which we have discussed here, of a series of novelties pertaining to the cycle of Christ's Life, did not, we may safely conclude, appear at random, as expressions of a wish to instill into the scenes new particulars for the sake of enhanced aesthetic pleasure. Rather, they must have come, as we have already stated, as the answers to the exigencies posed by the theological discussions and deliberations of the day. The urge to inflate the pictures with a deeper and more many-layered meaning was caused by the religious upheavals of the advanced seventh century, of which Kartsonis has given an apt summation. This was the ferment from which "The Anastasis" did issue, but which also triggered the work of creation, recasting and revision which took place in the circle of iconographers engaged in the inventing of New Testament illustration.

Christ's Birth, the scenes from His Passion, and the Miracle of His Resurrection and Appearances, were to be broadcast more convincingly; not, however, as dramatic events per se but as important doctrinal matter. For this end, smaller or larger amendments to the traditional iconography were performed. A point not to be overlooked, is how this renewal was carried out largely with the help of new artistic means. Although still shrouded in enigma, because of a fundamental lack of relevant sources, the participation, respectively, of the two groups of picture-makers who 
partook in the iconographical renewal of the outgoing seventh century, may now be easier to define. We have already seen with what singular sense for both the instructional and the narrative features the extracts which were to be illustrated were culled from the Scriptures and the apocrypha, to elucidate points of particular importance to dogma. Still, the theologians, the group we would be inclined to call the intellectual component in this collegium, may not have had the sole responsibility for the episodes chosen. To guide them, the artists with their grip on aspects of the laws of composition and their knowledge of the expressiveness of human form, brought to the work what one must believe was a fundamental input.

Above, the expression 'a master's eye' has been used in describing the competence with which the artists belonging to the team of 'iconographers' carried out their part of the work of visualizing the scenes singled out for illustration. But what was, in fact, their exact role, within the group, in the compounding of the new imagery? Was their role purely receptive, i.e. that of carrying out, passively, the drawing of the subjects which were imposed upon them by the theologians? Did these drafts come to them with all particulars specified, or was the artists' faction engaged, already from an early stage in the process, in evaluating the material which was to be given life by being transposed into visual form? The choosing of the details, to inform and make susceptible the stories to be represented, was a serious matter and essential for the reactions which the pictures were to evoke from the viewer.

In this collective endeavour, only the artists owned the knowledge of how to make the many parts of a given composition work together, and were trained in the depiction of the pliable human form. It should be suggested that with this kind of talent they had a vote not only in the hammering out of important details which were crucial to the transmittal of content, but also, partly, in the selection of the episodes which were to be represented, their task being the appraisal of the 'representability' of the source material extracted for them by the theologians. The artists' grip on the levers which control the flow of visual stimuli gave them no little influence on the process in which they were partaking. The building up of the 'stage' on which the plot was to evolve, and the distribution of and interconnection between the protagonists were under their control. ${ }^{28}$

The substitution of the "Women at the Grave" with "The Apostles at the Tomb" introduced a dynamic and eyecatching element in the depiction of the very moment in which the two disciples did realize that Christ had risen, and displayed the impact which the discovery had on them through their 'body language'. Likewise, the inclusion of the cutting of Malchus'ear in the Judas scene led to an intensifying in the performance of the characters who people the scene: Christ. the compositional lynchpin in the centre of the scene, is approached from the right by Judas, but in a sudden 'contrapostal' movement He turns away to look in the opposite direction: His turning links, potently, the new addition, the ear-cutting, to the drama of the main action which takes place in the centre of the panel. No doubt the adjunct to the story contributed to a heightening of

28. As to the educational level of the Byzantine artists, it was above the average. P. Lemerle observed that the artists "belonged to the group who received a schooling up to the age of ten or eleven and could read, write and count. Like many Byzantine monks, they were literate, but not "educated"; cited from Cormack 1978, 160. 
the tension radiating from the scene. One feels an artist's hand in the creation of the highly charged 'signs' embraced by the panel.

Still, another main example of the artists' involvement in the creation of Gospel illustration is the design which illuminates the representation of "The Appearance at the Lake Tiberias". Here, three moments of the narrative coalesced, Christ Appearing near the lake, John's apprehension of Him, and Peter swimming towards the shore. The scene is a high point in the art of image construction, its three main components distributed evenly on the picture plane but linked by means of glances and poses: decisive is the pointing gesture of John's hand, which via the swimming figure with its energetic movements leads the spectators' glance towards Christ on the shore. Behind the composition lies a work of extensive artistic cogitation, which may have regarded the choice and number of protagonists as well as the parts to be played by them in the visual drama to be staged.

A conclusion to draw from these observations could be that the artists' faction among the iconographers may have had a hand already in the initial consultations which preceded the decisions made by the group of image-makers. What else could produce such balanced and trenchant, but at the same time intensely agitated, pictorial matter? A remarkable colloquium must have taken place, some time before the year 700 A.D, when a 'new edition' of New Testament scenes was in preparation, bringing together specialists of extraordinary capabilities. The symbiosis of an intellectual and an artistic approach to picture-making resulted in the fashioning of a series of designs which were not short-lived and quickly consigned to oblivion, but became the matrix for Byzantine art of the successive centuries.

We have seen that "The Anastasis" is not the single instance of inspired image-creation in preiconoclastic art, as it was once thought to be, but is one among a series of newly-made or refurbished scenes from Christ's Life which pullulated at this particular juncture. As to the place in which the production of these prototypes occurred, few will disagree with the suggestion that the iconographical reform must have evolved in close proximity to a centre where the discussions on creed and dogma went on with an intensity strong enough to leave its mark also on the very form of the design in which the new pictures were cast. The dynamic 'style' seen in them is an indicator of the vigour with which these altercations took place. The regions at the Eastern Mediterranean point themselves out as the arena where the theological disputes which may have inspired the iconographers were both at their most pointed and subtle. ${ }^{29}$

Per Jonas Nordhagen

Heien 6

5037 Bergen

pjnordhagen@gmail.com

29. In Nordhagen 1992, I have suggested that the style visible in the frescoes of the early eighth century in Rome, with its technical brilliance conjuring up a tense and vivacious setting for the Gospel scenes, did not emulate antique painting for purely aesthetic reasons, i.e., 'to please the eye'. Instead, the 'Hellenism' visible in these scenes (and which is present in a supreme degree in the frescoes at Castelseprio) should be regarded an integral part of the iconography, i.e., as a means by which the episodes illustrated are injected with the capacity to stir compassion, to sharpen the message conveyed by the

narrative. To this end the Early Byzantine artist even revived the artistic means for the creation of the engaged (or direct) glance between participants, which heightens the drama in narrative scenes. This device consists in the rendering of the eye with two short dabs of colour, one dark to mark the pupil, the other a whitish highlight (The Frescoes, XVII, a; XIX; XXVII; XXXVIII, a; LXIII; LXIV). This painterly trick can be seen in the smaller Pompeian panels executed in a summary technique. 


\section{BIBLIOGRAPHY}

Ballardini, A. 2011: "Un oratorio per la Theotokos: Giovanni VII (705-707) committente a San Pietro", in Medioevo, Atti del convgno internazionale di studi, Parma, 21-26 settembre 2010 (a cura di A.C. Quintavalle), 94-116.

Belting, H. 1962: Die Basilica dei SS. Martiri in Cimitile und ihr frühmittelalterlicher Freskenzyklus, Wiesbaden.

Bognetti, G.P., Chierici, G., Capitano d'Arzago, A.D. 1948: Santa Maria di Castelseprio, Milan.

Bovini, G. 1958: Mosaici di S. Apollinare Nuovo di Ravenna. Il ciclo cristologico, Florence.

Cormack, R. 1978: "Painting after Iconoclasm", in A. Bryer and J. Herrin (eds.), Iconoclasm. Papers given at the ninth Spring Symposium of Byzantine Studies, University of Birmingham March 1975, Birmingham, 35-44.

Didron, M. 1845: Manuel d'iconographie chrétienne greque et latine.

Grabar, A. 1974 (1936): L'empereur dans l'art byzantin. Recherches sur l'art officiel de l'Empire d'Orient, Paris.

Grabar, A. 1968: Christian iconography. A study of its origins (The Mellon Lectures), Princeton.

Grabar, A. 1979: Les voies de la creation en iconographie chrétienne, Paris.

Grimaldi, G. 1618: "Opusculum de sacrosancto Veronicae Sudario, ac lancea quae Salvatoris nostri Jesu Christi latus aperuit in Basilica Vaticana maxima veneratione asservatis", MS. II-III-173, Bibl. Nazionale, Florence.

Kartsonis, A. 1986: Anastasis. The Making of an Image, Princeton.

Millet, G. 1916 (reprinted 1960): Recherches sur l'iconographie de l'Évangile aux XIV., XV. et XVI. Siècle (Bibliothéque des Écoles francaises d'Athénes et de Rome, 109), Paris.

Nordhagen, P.J. 1965: "The Mosaics of John VII (705-707 A.D.). The Mosaic Fragments and their Technique", ActaAArtHist, II, 121-166.
Nordhagen, P.J. 1968: The Frescoes of John VII (705-707 A.D.) in Santa Maria Antiqua in Rome (ActaAArtHist III).

Nordhagen, P.J. 1972: "The Integration of the Nativity and the Annunciation to the Shepherds in Byzantine Art", in Actes du XXIIe Congrès international d'histoire de l'art. Budapest 1969 Budapest, 253-257.

Nordhagen, P.J. 1990: Studies in Early Medieval and Byzantine Painting. Selected articles, London.

Nordhagen, P.J. 1992: "Zwischen Ikonographie und Stil. Zur Semiotik der frühen byzantinischen Kunst", in Festschrift Manuel Chatzidakis, Athens, 417-421.

Ristow, G. 1971: "Geburt Christi”, in K. Wessel (ed.), Reallexikon zur byzantinischen Kunst, II, Stuttgart.

Schapiro, M. 1979: "The Frescoes of Castelseprio", Late Antique, Early Christian and Medieval Art. Selected Papers, New York, 67-142.

Thüner J. 1994: "Verrat des Judas" and "Der Judaskuss", in E. Kirschbaum, G. Bandmann (eds.), Lexicon der christlichen Iconographie, Bonn/Rome.

van Dijk, A. 1995: "The Oratory of John VII (705-707) in Old St. Peter's" (Phd dissertation), MS, The John Hopkins University.

van Dijk, A. 1999: “The Angelic Salutation in Early Byzantine and Medieval Annunciation Imagery", $A B$ 81, 420436.

Weitzmann, K. 1952: The Fresco Cycle of Santa Maria di Castelseprio, Princeton.

Wilhelm, P. 1994: "Geburt Chisti”, in E. Kirschbaum, G. Bandmann (eds.), Lexicon der christlichen Ikonographie, Bonn/Rome, 2.

Wilpert, J. 1917: Die römischen Mosaiken und Malereien der kirchlichen Bauten vom 4.-13. Jahrhundert, IV, Freiburg. 